\title{
The Radical Avant-Garde and the Obsession for a New Beginning
}

\author{
ȘTEFAN GAIE \\ Affiliation: University of Oradea, Romania, \\ Department of Arts \\ E-mail: stgaie@yahoo.com
}

\begin{abstract}
Rising in an extremely troubled context in the first decades of the 20th century, the so-called radical avant-garde (especially Futurism, Dadaism, Suprematism and Constructivism) obsessively pleaded for a "new beginning", a real "restart" of art. Its discourse, both theoretical, of the avant-garde manifestos, and visual, aimed at giving alternatives for what were meant to become the new benchmarks of art history.

We know today that the face of art definitely changed as a result of avant-garde assaults. Even if the effects of this radicality faded in the past century, they are still evident. This study is intended to understand this radicality within the context of its occurrence, to find some of its constants, and to follow its effects upon contemporary art, in order to attempt to understand to what extent we can speak about a success or a failure of the avant-garde.
\end{abstract}

Keywords: art history, modern art, avant-garde, beginning, contemporary art

\section{Introduction}

On April 7, 1917, it was Hugo Ball's turn to give a lecture on his favorite artist at Galerie Dada in Zürich. It did not surprise anyone that he had chosen Kandinsky, with whom he met in München in 1912 and whose spiritual interpretation of the purpose of art in a materialistic age impressed him deeply. However, before referring to the painter Kandinsky, Ball decided to speak about "The Age" and its condition. There was no wonder since Europe was on fire at the time.... Here are the words with which he began his lecture:

God is dead. A world disintegrated. I am dynamite. World history splits into two parts. 
There is an epoch before me and an epoch after me. (...) A thousand-year-old culture disintegrates. There are no columns and supports, no foundations any more-they have all been blown up. (...) The transvaluation of values came to pass (Ball, 1996, p. 223).

The intuition that European civilization was going through a time of deep crisis and that it was at a crossroads had become commonplace for the artists and intellectuals of the age. There are countless testimonies in this respect. Let's point out just two more examples; so as not to leave the impression of favoring artists, I chose a scientist and a philosopher. Max Planck, a Nobel Prize laureate in Physics in 1918, noted in an essay published in 1933:

We are living in a very singular moment of history. It is a moment of crisis, in the literal sense of that word. (...) Many people say that these symptoms mark the beginnings of a great renaissance, but there are others who see in them the tidings of a downfall to which our civilization is fatally destined. Formerly it was only religion, especially in its doctrinal and moral systems, that was the object of sceptical attack. Then the iconoclast began to shatter the ideals and principles that had hitherto been accepted in the province of art. Now he has invaded the temple of science. There is scarcely a scientific axiom that is not nowadays denied by somebody (Plank, 1933, p. 64).

Edmund Husserl, the founder of phenomenology, stated in a lecture delivered at the Vienna Cultural Society on May 7, 1935:

The crisis of European existence can end in only one of two ways: in the ruin of a Europe alienated from its rational sense of life, fallen into a barbarian hatred of spirit; or in the rebirth of Europe from the spirit of philosophy, through a heroism of reason that will definitively overcome naturalism. Europe's greatest danger is weariness. Let us as "good European" do battle with this danger of dangers ... If we do, ..., the phoenix of a new inner life of the spirit will arise ... (Husserl, 1965, p. 192).

We could fill numerous pages with such alarm signals generated by the era. We will stop for the time being but we must bear in mind, in addition to the signals, the intense use of the figurative language: "crisis", "barbarian hatred", "alienated Europe", "rebirth", "battle", etc. There seemed to be only two alternatives: doom or a new beginning. Within this context, Virginia Wolf's famous words become perhaps clearer: "on or about December 1910, human character changed" (Woolf, 1966, p. 320). This accuracy of the date is intended to be nothing more than mere irony. We know today that the statement was made right after the shock caused by the opening of the First Post-Impressionist Exhibition, in London, on November 8; it introduced the works of Cézanne, Matisse, Van Gogh and Gauguin to the 
British art-loving public.

In the meanwhile, these intuitive thoughts and ideas have become a certainty for us, contemporaries who, a century later, have the ability to follow this rupture happening in all fields of humanity. Modernism-written in an important work dedicated to 20th century culture, namely The Cultural Contradictions of Capitalism by Daniel Bell-was "responsible for one of the great surges of creativity in Western culture" (Bell, 1978, p. $X X I I)$. Such a transformation implies a profound upheaval in consciousness, perception, value systems and ideology, influencing our way of understanding both ourselves and the world as a whole and having an analogous impact on art, science, philosophy, religion and political theory. As we have seen, this change was perceived by even its contemporaries who strongly felt that European civilization was experiencing the overthrow of the most important convictions and conceptual models whose origins were traced back to the thinking of Plato or Aristotle.

Any attempt to outline the profile of this so complex epoch, with which we are at least partially contemporary today, must begin from that "transvaluation of all values" that Hugo Ball was talking about (the expression belongs, of course, to Nietzsche, a true fetishthinker of the age). The complexity of this disruption makes it impossible to present it in an exhaustive manner. What is certain, however, is the fact that it has touched all areas of human existence.

Signals were coming from all sides, mainly from least-expected areas, like science. Research in the fields of subatomic physics and astrophysics conducted by the extraordinary generation of physicists around the 1900s, reconfigured the understanding of the way in which physical reality functions. Albert Einstein, Louis de Broglie, Erwin Schrödinger and Paul Dirac (to name just a few) demonstrated that, beyond the seemingly stable and harmonious world of classical physics, there is a "different world" that cannot be described in terms of Newtonian physics. If, for almost two thousand years, Euclid's Elements were considered to provide a complete and accurate image of the physical space, Henri Poincaré, in his suggestively entitled book Science and Hypothesis (1905), came to the conclusion that Euclidean geometry is conventional and relative:

What, then, are we to think of the question: is Euclidean geometry true? It has no meaning. We might as well ask if the metric system is true, and if the old weights and measures are false; if Cartesian co-ordinates are true and polar co-ordinates are false. One geometry cannot be more true than other; it can only be more convenient (Poincaré, 1905, p. 59). 
As with Newtonian physics, Euclidean geometry continues to be operational only on the scale of everyday experience, and Poincaré noted that, beyond this area, there were "other worlds" where applying non-Euclidean geometries was far more "convenient". As for this radical change in the concept of physical reality, Werner Heisenberg wrote down that

... modern physics is in some way extremely near to the doctrine of Heraclitus. If we replace the word "fire" with the word "energy" we can almost repeat his statements word for word from our modern point of view (Heisenberg, 1958, p. 63).

In essence, what scientists ascertained right after 1900 was that things were not what they seemed to be, that 19th century certainties were not as certain. To this state of confusion, created by physics and mathematics, a certain book published in 1900 brought its major contribution: Die Traumdeutung, written by a Viennese psychologist, Sigmund Freud. Readers were stunned by the striking similarities with the ideas presented by contemporary physicists and mathematicians:

The unconscious is the true psychical reality; in its innermost nature it is as much unknown to us as the reality of the external world, and it is as incompletely presented by the data of consciousness as is the external world by the communications of our sense organs (Freud, 2010, p. 607).

The corrosive impact of Freud's thinking upon 19th century assumptions regarding the inherent rationality and morality of human nature is difficult to overestimate. The human ego, Freud claims, is nothing more than a cluster of discrete structures without any substantial unity, and, correspondingly, the structure of human culture was built at the cost of suppressing the subconscious.

The parallelism between physics, mathematics, and psychoanalysis is more than evident. Ball reinforces it during his lecture on Kandinsky:

Three things have shaken the art of our times to its depths, have given it a new face, and have prepared it for mighty new upsurge: the dissapearance of religion induced by critical philosophy, the dissolution of the atom in science, and the massive expansion of population in present-day Europe (Ball, 1996, p. 223).

And the consequences are devastating:

Man lost his divine countenance, became matter, chance, an aggregate, animal, the lunatic product of thoughts quivering abruptly and ineffectualy. Man lost the special position that reason has guaranteed him. He became a particle of nature, seen (with- 
out prejudice) as a froglike or storklike creature with disproportionate limbs, a wedge jutting out of his face (called "nose"), and flaps protruding from his head (which people used to call "ears"). Man, stripped of the illusion of godliness, became ordinary, no more interesting than a stone, and constructed and ruled by the same laws as stone; he vanished in nature; one had every reason to avoid giving him too close a look, unless one wanted to loose, in terror and disgust the last remnant of respect for his desolate reflection of the dead Creator (Ball, 1996, pp. 223-224).

If physics redefines physical reality and psychology redefines psychic reality-i.e. each of the two sciences basically rethinks its own object of study-art will also engage itself in reconsidering its own object, that is "art", as it was configured under the auspices of modernity. This was the crucial task undertaken by artists who would later become the "historical avant-garde". This task suited them like a glove, and the attack on the art institution would prove to be devastating.

Who were the avant-garde artists? The idea of avant-garde first appeared in France, in the midst of utopian socialism in the early 19th century. The idea-obviously taken from the military and political vocabulary-acquires precise aesthetic connotations for the first time with D. Levardant, in 1845:

Art, the expression of Society, communicates, in its highest soaring, the most advanced social tendencies; it is the precursor and the revealer. So that in order to know whether art fulfils with dignity its role as initiator, whether the artist is actually of the avantgarde, one must know where Humanity is going, and what the destiny of our species is (Apud Călinescu, 1987, pp. 106-107).

The importance of this origin of the avant-garde is underlined by Adrian Marino in the following words:

All the fundamental notes of the concept begin to group together around this "military" nucleus, by extension: militant, ... . A fact often overlooked: before setting up a "current" or an aesthetic way, the avant-garde defines an attitude of life, a way of conceiving and living existence, almost a Weltanschauung (Marino, 1973, pp. 179-180).

During the 19th century, a number of French writers and artists, especially those grouped in the realm of realism, united more or less consciously, placing themselves in a critical position towards bourgeois society and what was being perceived as official culture. The radicalization of this position became more intense towards the end of the century, yet it remained constantly peripheral. 
The term "avant-garde" really came to the fore during World War II in the writings of the American critic Clement Greenberg, and was later intensely theorized. Although it imposed itself, being universally accepted as designating the artistic currents that appeared in the first decades of the 20th century (over forty!), analysts agreed that the concept is far too broad to be approached as a whole. The reason for this precaution was seized by Adrian Marino in the following words: "Heterogeneous, pulverized, often chaotic, the "avant-garde" defies by its very nature, description, clarification, precise definition" (Marino, 1973, p. 177). This is why syntheses are extremely rare, and when they occur, they are intensely criticized by specialists. Peter Bürger's Theorie der Avantgarde (1974) is no exception. However, we continue to resort to this work because, beyond its sometimes forced generalizations, it has managed to highlight exactly what we are interested in: the attack of the historical avant-garde on the institution of art. The book is important primarily because its author tries to individualize the progressive artistic movements of the early 20th century, distinguishing them both from the avant-garde of the previous century, but also from other contemporary art movements of the time. More specifically, Bürger is interested in what he calls the "historical avant-garde", i.e., the radical "hard core" of the avant-garde of the first two decades of the 20th century: Futurism, Dadaism, Surrealism and Russian Constructivism. The German theorist considers that what brings together the so diverse movements of the avant-garde, is, more than anything else, the attack focused on the institution of art, doubled by the constant attempt to bring art as close to life as possible. Indeed, the stakes of the avant-garde were not just aesthetic. Bridging the gap between art and life, the avant-garde artists set out to revolutionize both. Bürger repeatedly emphasizes that the movements of the avant-garde

... can be defined as an attack on the status of art in bourgeois society. What is negated is not an earlier form of art (a style) but an institution that is unassociated with the life praxis of men. When the avant-gardistes demand that art become practical once again, they do not mean that the contents of works of art should be socially significant. The demand is not raised at the level of the contents of individual works. Rather, it directs itself to the way art functions in society, a process that does as much to determine the effect that works have as does the particular content (Bürger, 1987, p. 49).

In his analysis of the self-critical impulse of art, Bürger highlights the importance of the concept of the "institution of art" and he uses it to study the social administration of the aesthetic sphere.

It is important to remember that the way we understand art today took shape during the 18th century. Like many other modern ideas, such as "rationality", "science", "nation," "art" 
became a point of reference for all modernity, fulfilling a new social function and being responsible for creating a new category of objects, the so-called "objects of art". The development of most modern artistic practices was profoundly influenced by the logic that resulted from the emergence of two disciplines that became essential for shaping the world of modern art: aesthetics and art history. The new concept of art, as a distinctly modern phenomenon, was the result of the concerted effort of these two disciplines. Aesthetics played such an important role in establishing the new field of art that it would be no exaggeration to say that it was responsible for the way art was understood in modernity. The way in which aesthetics managed the appearance, the definition and delimitation of this new field was to be found, during the 19th century, in the aesthetic doctrine of the autonomy of art and later, at the beginning of the 20th century, it culminated in the aesthetic formalism. This aesthetic understanding of art led to the transformation of art into an autonomous, self-referential field, one that would be evaluated only in its own terms, that is, only according to its internal standards. The doctrine of the autonomy of art would lead to an increasingly accentuated ontological distinction between art and the other things of the world; also, the values and standards by which art is judged would become immeasurable compared with the other kinds of values and standards that governed ordinary life. The essential feature of the development of art in the bourgeois society of the 18th and 19th centuries was, as Bürger remarks, the increasing emphasis on aesthetic autonomy, a condition defined by the German theorist as "the independence of the work of art from its extra-aesthetic use" (Bürger, 1987, p. 110). This process of liberating art from all its external practical requirements culminated in the aesthetic movement. 19th century aesthetics appeared as a radical attempt to reposition itself, resulting in an increasing concern for the artistic environment. The historical avant-garde, which reached maturity in the 1920s, rose up against this isolation of art. Its importance lies in the fact that this was the first artistic movement in the history of Western art that conceptually raised the issue of the separate social status of modern art. In doing so, the avant-garde opened the possibility of a new understanding of art, an understanding that helped art insert into everyday life, rather than seek to escape from it. The historical avant-garde launches a direct and open attack on the very autonomous status of art, so what is denied is not an earlier form of art, but art as an institution. In other words, art enters the era of "self-criticism" (Bürger, 1987, p. 22).

It is essential to remember here that the goal of the historical avant-garde was not only to record the experience of modernity but, more importantly, to deconstruct that experience. This is the case, for example, with Dadaism. It was one of the most important phenomena of interwar culture until around 1924 when its energies were taken over and 
transformed by the surrealists. The various manifestations of the international Dada were rapidly spreading from Zürich and New York to the major European cultural centers. Dada was not an organized movement (no matter how hard Tristan Tzara had tried), but rather its sympathizers shared similar positions and reactions to the disastrous consequences of mechanization and war, in particular. This was the main reason why Dadaism gained a large number of adherents in post-war Germany. We can hear the echo of the post-war traumas in the language of the manifesto of the Dadaist group in Berlin in 1918:

"Life appears as a simultaneous muddle of noises, colours and spiritual rhythms, which is taken unmodified into Dadaist art, with all the sensational screams and fevers of its reckless everyday psyche and with all its brutal reality. (...) Dada is the international expression of our times, the great rebellion of artistic movements, the artistic reflex of all these offensives, peace congresses, riots in the vegetable market, midnight suppers of the Esplanade, etc., etc." (as cited in Richter, 1965, p. 106).

The First International Dada Fair (Berlin, 1920) displayed, among other more than two hundred works, a stuffed military uniform topped by a papier-mâché pig's head, dangled from the ceiling, next to a large painting by Otto Dix depicting war cripples-a savage indictment of war, mocking postwar hopes.

The avant-garde artists shared a political desire to look beyond artistic creation to the role of art in building a new world. Their belief in the regenerating capacities of art had been a constant in avant-garde philosophy. However, to achieve this goal, art had to be revolutionized, redefined, and brought back into contact with everyday life. In such a short time (about 2 decades) they challenged all conventions, rules, and aesthetic presuppositions they could identify. The logical conclusion reached by the avant-garde artists was the need for a new beginning. There was only one alternative: the doom. This "new beginning" had to be "new" in the most radical sense of the word. It should not preserve any impurities, nothing reminiscent of that completely perverted "old" state of the art they had so vehemently condemned to death. This explains, as Boris Groys remarks, the fascination exerted on the avant-garde artists by the dogma of the creation of the world from nothing or from the original chaos:

Many artists of the classical avant-garde in fact set out from this dogma in reflecting on their own creativity. Malevich talks about his creation of the suprematist world out of the void. The constructivists and Dadaists in Russia, Germany, or France also talk about the void as the origin of their creative work (Groys, 2014, pp. 76-77). 
This new beginning takes extremely different forms. Let us give, at random, a few examples: zaum language ('transrational'), invented by the Russian avant-garde poet Aleksei Kruchenykh; Kazimir Malevich's aesthetic gnosis ("I have transformed myself into the zero of form, (...) and through zero I have reached creation, that is suprematism, the new painterly realism-nonobjective creation" (Malevich, 1915, pp. 128-133); the utopian ideal of universal renewal through the language of forms, proposed by the De Stijl group; Mondrian's Neoplasticism; the effort of Russian Constructivists to create a new aesthetic vocabulary, universal forms, and images, striving to represent the world in the most objective way, etc. And this "novelty" did not only reshape the art world (we cannot imagine the world of contemporary art without collage, montage, ready-made, etc.), leaving as a legacy the probably most frequently repeated question all along the 20th century ("What is art?"), but it also remodeled our world since the art of the avantgarde managed to reach an essential structure of our present state, invading our homes, streets, and cities.

Figure 1.

From left: Russolo, Carrà, Marinetti, Boccioni and Severini in front of Le Figaro, Paris, 9 February 1912

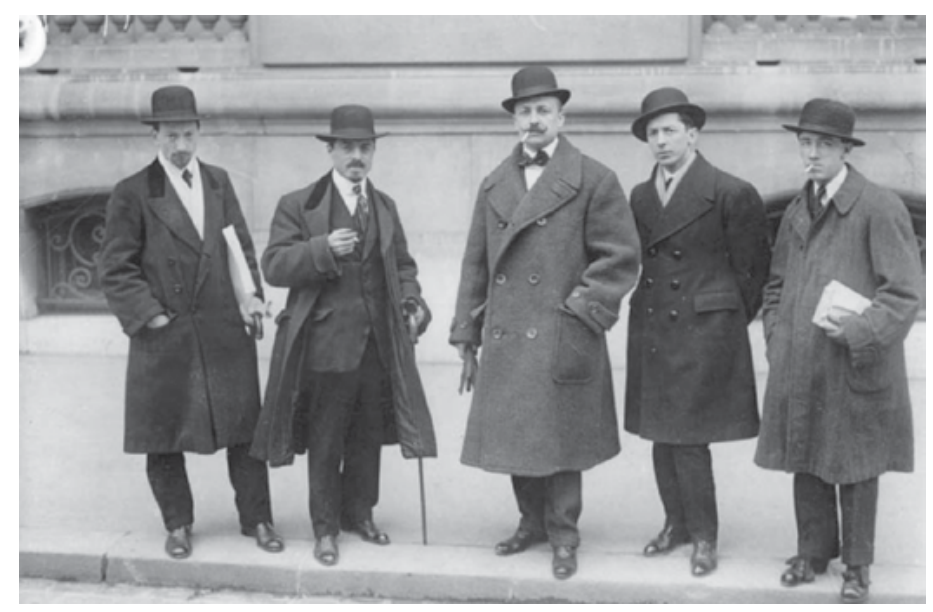

Commenting on the well-known photograph taken by an anonymous of the group of five initiators of futurism during their visit to Paris in 1912, Hans Belting remarks ironically, but with good reason:

Futurist paintings and sculptures may still look modern-in fact, more modern than anything today's art has to offer-but these gentlemen themselves do not. They were still young then, but their very clothing reveals how old modernism has meanwhile become. They look as if they are in costume, wearing the clothes of the bourgeois society against which they have declared war. But this intention does not make the era any less remote from us (Belting, 2003, p. 28). 
Indeed, according to our tastes, at least, the five signatories of the incendiary futuristic manifestos do not look barbarians at all and do not seem ready to set fire to the old world to make way for a new one. Let us not be misled, however. Their creations, and especially their ideas, like those of other avant-garde artists, remain extremely modern to this day, or, to paraphrase Belting, more modern than most of the ideas circulating today in the art world.

However, there is talk of the failure of the avant-garde. It was Bürger who set the tone. The German theorist believes that the avant-garde failed to achieve its goal of destroying the institution of art in order to dissolve the boundaries between art and life. The obvious proof: the institutionalization of the avant-garde. The failure of the avant-garde as an artistic revolution would coincide, according to Bürger, with the beginning of its reign as predominant aesthetics, a process that begins with the inauguration of the Museum of Modern Art (MOMA) in New York, or with the monopolization of the avant-garde aesthetics by the consumer society. In other words, the failure of the avant-garde would coincide with the moment when its protests against art as an institution became, through a "perfidious" strategy of the institution, accepted as art. This is why Bürger disregards the neo-avant-garde of the 1960s, seeing it as a mere sterile "repetition" of the historical avant-garde. Disagreeing with Bürger, American art historian Hal Foster argues in his book The Return of the Real that the failure of the historical avant-garde is not total, as criticism of art institutions was revived by the second wave of the avant-garde (neoavant-garde) in the 1960s.

However different aesthetically and politically, both practices contest the bourgeois principles of autonomous art and expressive artist, the first through an embrace of everyday objects and a pose of aesthetic indifference, the second through the use of industrial materials and the transformation of the function of the artist (Foster, 1996, p. 4).

Foster believes that the historical avant-garde failed only within the context of its age, but the effects of its critique spread, influencing decisively the neo-avant-garde. And not only that, we would add. Without succeeding in destroying the institution of art, the avantgarde managed to raise important questions about the validity of "conventional" norms and criteria. A proof of its success was precisely the disclosure of the conventionality of all criteria and norms and implicitly the impossibility of any artistic movement or particular art form to issue claims of universal validity. And this has become evident in the art world, especially since the 1960s, after the American Abstract Expressionism, probably the last art movement that issued such claims. 
Despite its flaws and often unhappy mésalliances, the avant-garde enriched our culture with a complex understanding of the human personality and the relationships with its environment; it transformed the way we connect the past to the present and gave us new ways of representing the world and our place in it, ways that were non-existent or barely intuited before 1900. The avant-garde campaigned for the return of art to the "agora", for its reinvestment with "utility". Using the cognitive force of art to defamiliarize a specific set of institutionalized conventions, the expressionists unmasked the true image of war and the dehumanized man, the surrealists explored the depths of the human psyché, opening new windows to look at the world and ourselves, the Dadaists signaled the dangers of reifying language, etc. Yet, most importantly, the avant-garde artists did their best to keep alive our capacity for wonder and delight in the midst of the industrial discipline, bureaucratic routine, quantification, and the invasion of commodification and market imperatives in all aspects of life.

The crucial problem that avant-garde was facing at that time can be described in the following terms: did modern society, technology, art, education impose a rupture with the Western humanist cultural tradition, or was it a mere reconstruction of its venerable ideas in the light of new experiences and circumstances? This was probably the most difficult problem for the avant-garde. It assumed it, explored it intensely, but never solved it sharply, oscillating dramatically between modernolatry and modernophobia. It remains, in fact, a problem for us postmodernists too.

The assumption providing a basis for the avant-garde movements was that the relationship between art and society had fundamentally changed, that the old ways of seeing were no longer adequate, and new ones had to be found. This assumption is obviously correct. Therefore, the problem of the failure of the avant-garde is a false one. As Daniel Bell rightly remarks:

The commonplace observation that today there is no longer a significant avant-gardethat there is no longer a radical tension between new art which shocks and a society that is shocked-merely signifies that the avant-garde has won its victory. A society given over entirely to innovation, in the joyful acceptance of change, has in fact institutionalized the avant-garde ... (Bell, 1978, p. 35).

Or, to use Hal Foster's words, the avant-garde, as a tradition, won, even if its victory was "à la Pyrrus" (Foster, 1986, p. IX). 


\section{References}

Ball, Hugo. (1996). Flight out of Time: A Dada Diary. University of California Press.

Bell, Daniel. (1976). The Cultural Contradictions of Capitalism. Basic Books.

Belting, Hans. (2003). Art History after Modernism. The University of Chicago Press.

Calinescu, Matei. (1987). Five Faces of Modernity. Modernism. Avant-Garde. Decadence. Kitsch. Postmodernism. Duke University Press.

Foster, Hal. (1996). The Return of the Real. The Avant-Garde at the End of the Century. The MIT Press.

Foster, Hal (ed.). (1986). The Anti-Aesthetic. Essays on Postmodern Culture. Bay Press.

Freud, Sigmund. (2010). The Interpretation of Dreams. Basic Books.

Groys, Boris. (2014). On the New. Verso.

Heisenberg, Werner. (1958). Physics and Philosophy. The Revolution in Modern Science. Harper \& Brothers Publishers.

Husserl, Edmund. (1965). Philosophy and the Crisis of European Man, in Edmund Husserl, Phenomenology and the Crisis of Philosophy. Harper \& Row. Publishers.

Malevich, Kazimir. (1988). From Cubism and Futurism to Suprematism: The New Painterly Realism, 1915, in Russian Art of the Avant-Garde: Theory and Criticism, 1902-1934. John E. Bowlt (ed.). Thames and Hudson.

Marino, Adrian. (1973). Dicţionar de idei literare. Editura Eminescu.

Plank, Max. (1933). Is the External World Real?, in Where is Science Going, James Murphy (ed.). Ox Bow Press.

Poincaré, H. (1905). Science and Hypothesis. The Walter Scott Publishing Co. Ltd.

Richter, Hans. (1965). Dada: Art and Anti-Art. Thames and Hudson.

Woolf, Virginia. (1966). Mr. Bennett and Mrs. Brown. in Collected Essays, I. The Hogarth Press. 